\title{
Doxorubicin toxicity can be ameliorated during antioxidant L-carnitine supplementation
}

\author{
Othman A. Alshabanah, ${ }^{1, *}$ Mohamed M. Hafez, ${ }^{1}$ Mohamed M. Al-Harbi,, Zeinab K. Hassan, ${ }^{3}$ Salim S. Al Rejaie, ${ }^{1}$ Yosef A. Asiri ${ }^{2}$ \\ and Mohamed M. Sayed-Ahmed ${ }^{1}$
}

'Department of Pharmacology; College of pharmacy; ${ }^{2}$ Department of Clinical Pharmacy; College of Pharmacy; ${ }^{3}$ College of Science; Zoology Department; King Saud University; Riyadh Kingdom of Saudi Arabia

Key words: doxorubicin, L-carnitine, hepatotoxicity, gene expression, antioxidant agent

\begin{abstract}
Doxorubicin is an antibiotic broadly used in treatment of different types of solid tumors. The present study investigates whether L-carnitine, antioxidant agent, can reduce the hepatic damage induced by doxorubicin. Male Wistar albino rats were divided into six groups: group 1 was intraperitoneal injected with normal saline for 10 consecutive days; group 2, 3 and 4 were injected every other day with doxorubicin ( $3 \mathrm{mg} / \mathrm{kg}$, i.p.), to obtain treatments with cumulative doses of 6,12 and $18 \mathrm{mg} / \mathrm{kg}$. The fifth group was injected with L-carnitine $(200 \mathrm{mg} / \mathrm{kg}$, i.p.) for 10 consecutive days and the sixth group was received doxorubicin $(18 \mathrm{mg} / \mathrm{kg})$ and L-carnitine $(200 \mathrm{mg} / \mathrm{kg})$. High cumulative dose of doxorubicin (18 mg/kg) significantly increases the biochemical levels of alanine transaminase, alkaline phosphatase, total bilirubin, thiobarbituric acid reactive substances (TBARs), total nitrate/nitrite (NOx) $p<0.05$ and decrease in glutathione (GSH), superoxide dismutase (SOD), glutathione peroxidase (GSHPx), glutathione-s-transferase (GST), glutathione reductase $(\mathrm{GR})$ and catalase (CAT) activity $\mathrm{p}<0.05$. The effect of doxorubicin on the activity of antioxidant genes was confirmed by real time PCR in which the expression levels of these genes in liver tissue were significantly decrease compared to control $\mathrm{p}<0.05$. Interestingly, L-carnitine supplementation completely reversed the biochemical and gene expression levels induced by doxorubicin to the control values. In conclusion, data from this study suggest that the reduction of antioxidant defense during doxorubicin administration resulted in hepatic injury could be prevented by L-carnitine supplementation by decreasing the oxidative stress and preserving both the activity and gene expression level of antioxidant enzymes.
\end{abstract}

\section{Introduction}

Doxorubicin (Dox) is among the first anthracycline antibiotics clinically used in cancer chemotherapy. ${ }^{1}$ Its clinical use in long-term treatments is limited by the development of free radicals induced toxicities, ${ }^{2}$ which are frequently lethal. ${ }^{1,3,4}$ Its metabolic activity causes generation of free radicals and induction of oxidative stress that correlated with tissue injury. ${ }^{5}$ Dox causes an imbalance between free oxygen radicals (ROS) and antioxidants enzymes resulting in tissue injury, ${ }^{6,7}$ that is confirmed by lipid peroxidation and protein oxidation in tissue. ${ }^{8}$ Dox had toxic effects on liver through increasing levels of superoxide dismutase (SOD), catalase (CAT) and glutathione peroxidase (GSHPx) enzymes in liver tissue which are found in antioxidant enzyme system. ${ }^{9,10}$ Regulation of these mediators has been considered for therapeutic necessity to prevent doxorubicin-induced toxicities in various organs. ${ }^{11}$

L-carnitine (4-N-trimethylammonium-3-hydroxybutyric acid) is a naturally occurring compound that is widely distributed in nature, especially in red meats and dairy products. L-carnitine, an endogenous mitochondrial membrane compound, is a small water soluble molecule. It derived from two sources: endogenous synthesis, low levels of carnitine can be synthesized, primarily in liver and, to a lesser extent, in kidneys and brain, and from exogenous dietary sources. ${ }^{12,13}$ It is absorbed in the intestine and distributed to various tissues, with skeletal and cardiac muscle stores accounting for more than $98 \%$ of the total carnitine pool. L-carnitine presents in both plasma and tissue as free carnitine or bound to fatty acids as acylcarnitine derivatives. ${ }^{14}$ Its main physical function is facilitating the transport of long chain fatty acids into mitochondria in order to enter the $\beta$-oxidation cycle.,15 By combination with carnitine to form acylcarnitine, acyl groups could be transferred from cytosolic coenzyme A on the outer surface of the mitochondrion membrane, then to the inner surface by exchange with free carnitine using an antiport mechanism. The acyl groups are then transferred from carnitine to coenzyme A within the mitochondrion. ${ }^{15}$ Carnitine has a protective effect on lipid peroxidation by reducing the formation of hydrogen peroxide ${ }^{16,17}$ and is associated with buffering of excess acylCoA, which is potentially toxic to the cells. It is also improve antioxidant status in rats and showed free radical scavenging activity as well. ${ }^{18}$ In addition, L-carnitine prevents the accumulation of free fatty acids and their toxic intermediates, thus 
Table 1. Primers sequence for glutathione peroxidase (GSHPx), Catalase (CAT), glutathione reductase (GR) and glutathione-s-transferase (GST) genes

Gene name

GSHPx

Catalase

5'-AGG TGA CAC TAT AGA ATA GTG GTT TTC ACC GAC GAG AT- 3'

GR

GST

Forward primer
Reverse primer

5'-AGA GCG GGT GAG CCT TCT- 3'
5'-GTA CGA CTC ACT ATA GGG ACA CGA GGT CCC AGT TAC

CAT - 3'
5'-CCA TGT GGT TAC TGC ACT ACT TCC-3'

5'-GTC AGC CTG TTC CCT ACA -3'
Table 2. The effect of doxorubicin on liver enzymes indices alanine transaminase (ALT), alkaline phosphatase (ALP), total bilirubin and total carnitine in rats

$\begin{array}{ccccc}\begin{array}{c}\text { Treatment } \\ \text { groups }\end{array} & \begin{array}{c}\text { Serum ALT } \\ (\mathbf{U} / \mathbf{d} \mathbf{l})\end{array} & \begin{array}{c}\text { Serum ALP } \\ (\mathbf{U} / \mathbf{d l})\end{array} & \begin{array}{c}\text { Serum bilirubin } \\ (\mathbf{m g} / \mathbf{d l})\end{array} & \begin{array}{c}\text { Total carnitine } \\ \text { (nmol/g wet tissue) }\end{array} \\ \begin{array}{c}28.3 \pm 2.59 \\ \text { Control }\end{array} & 292.6 \pm 4.46 & 0.389 \pm 0.030 & 552 \pm 1.022 \\ \text { L-Carnitine } & 29 \pm 2.10 & 277.5 \pm 4.88 & 0.399 \pm 0.44 & 799 \pm 2.99^{*} \\ \begin{array}{c}\text { Doxorubicin } \\ 6 \mathrm{mg} / \mathrm{kg}\end{array} & 60.3 \pm 2.81^{*} & 369 \pm 6.94^{*} & 0.95 \pm 0.083^{*} & 435 \pm 5.44^{*} \\ \begin{array}{c}\text { Doxorubicin } \\ 12 \mathrm{mg} / \mathrm{kg}\end{array} & 227.2 \pm 10.07^{*} \# & 421.5 \pm 2.072^{*} & 1.46 \pm 0.0 .080^{*} \# & 352 \pm 1.84^{*} \# \\ \begin{array}{c}\text { Doxorubicin } \\ 18 \mathrm{mg} / \mathrm{kg}\end{array} & 301.2 \pm 8.58^{*} \# & 626.6 \pm 39.16^{*} \# & 1.75 \pm 0.114^{*} \# & 302 \pm 3.65^{*} \# \\ \begin{array}{c}\text { Doxorubicin } \\ 18 \mathrm{mg} / \mathrm{kg}+\mathrm{L} \\ \text { Carnitine }\end{array} & 41 \pm 3.60 \$ & 277.9 \pm 6.16 \# \$ & 0.384 \pm 0.044 \# \$ & 524 \pm 3.12^{*} \# \$\end{array}$

of L-carnitine against Dox-induced oxidative hepatocyte injury.

\section{Results}

The cumulative hepatotoxicity of Dox was clearly featured by dose-dependent increase in serum biochemical markers, ALT, ALP and bilirubin (Table 2). The serum biochemical markers were significant increased with doxorubicin dose dependent manner. At the highest cumulative dose, $18 \mathrm{mg} / \mathrm{kg}$, Dox resulted in significant increase by $975 \%, 114 \%$ and $349 \%$ in ALT, ALP and Bilirubin respectively, compared to control group. L-carnitine supplementation alone showed no significant changes in biochemical markers. On the other hand admin-

preventing their harmful effects on mitochondrial and cell membranes. ${ }^{18}$ The protective effect of L-carnitine on kidney and heart tissues has been proved in some models involving oxidative stress. ${ }^{1,19,20}$ L-carnitine deficiency results in severe symptoms such as muscle weakness, cardiomyopathy, congestive heart failure, encephalopathy, hepatic insufficiency, impaired growth and development in children and neuromuscular disorders. ${ }^{21,22}$ Exogenous L-carnitine used in myopathies and cardiovascular disease, ischaemic heart disease and chronic haemodialysis patients and parenteral nutrition. ${ }^{23}$ L-carnitine protected cardiac cells against ischaemia, hypoxia and oxidative stress, by decreasing the levels of toxic acylCoA derivatives and regulating carbohydrate metabolism. ${ }^{24}$ The haemodialysis substantially reduces plasma and tissue carnitine levels. L-carnitine shows the most promise among supplement therapies for the management of fatigue in cancer patients. ${ }^{25}$ In addition, lymphocytes are enriched in carnitine suggesting that the carnitine system might have a considerable role in counteracting the impaired immune responses associated with ageing. ${ }^{25} \mathrm{~L}$-carnitine might improve immune system function by its antioxidant action. ${ }^{26}$ Also, L-carnitine has a protective effect against the toxic actions of different drugs, which induce oxidative stress and/or carnitine deficiency. It is used to treat adriamycin-induced cardiotoxicity ${ }^{1}$ and valproic acid-induced hepatotoxicity, ${ }^{14}$ neurodegenerative disorders, ${ }^{27}$ male infertility ${ }^{28}$ and AIDS patients ${ }^{25}$ and as an additive in extended platelet storages. ${ }^{29}$ Therefore, this study has been initiated to study the protective potential istration of L-carnitine in combination with high dose Dox (18 $\mathrm{mg} / \mathrm{kg}$ ) resulted in a complete reversal of Dox-induced increase in serum ALT, ALP and bilirubin to the control values.

Accumulative dose of Dox was resulted in a significant $41 \%$ decrease in total carnitine level in liver tissues compared to the control group. Administration of L-carnitine alone resulted in a significant $45 \%$ increase in total carnitine level in liver tissues as compared to the control group. On the other hand, administration of L-carnitine with Dox resulted in a complete reversal of Dox-induced decrease in total carnitine in liver tissues to the control values Table 2 .

The effect of Dox, L-carnitine and their combination on the oxidative, nitrosative stress biomarkers and indices of lipid peroxidation, TBARS, NOx and GSH in liver tissues are shown in Table 3. The highest cumulative dose of Dox resulted in significant $72 \%$ and $84 \%$ increase in TBARS and NOx respectively, and a significant $54 \%$ and $48 \%$ decrease in GSH and SOD respectively compared to the control group. There is no significant change in oxidative, nitrosative stress biomarkers and index of lipid peroxidation observed with L-carnitine supplementation alone. Treatment with L-carnitine resulted in a complete reversal of Dox-induced increase in TBARS and NOx and decrease in GSH in liver tissues to the control values. There is a significant increase of these biomarkers in the started dose of Dox $(6 \mathrm{mg} / \mathrm{kg})$ compared to the last cumulative dose.

Table 4 showed that the high dose of Dox resulted in significant decrease of antioxidant enzymes activity of GSHPx, CAT, GR and GST, compared to normal and L-carnitine-supplemented 
rats. In L-carnitine supplemented rats, $\mathrm{L}$-carnitine resulted in a complete reversal of Dox-induced decrease in GSHPx, CAT, GR and GST in liver tissues to the control values. There were significant decrease in the antioxidant enzymes by 49\%, 23\%, 49\% and 14\% of GSHPx, CAT, GR and GST respectively in the dose of Dox $(18 \mathrm{mg} / \mathrm{kg})$ compared to the dose of $6 \mathrm{mg} / \mathrm{kg}$.

Table 5 showed the effect of doxorubicin, L-carnitine and their combination on the antioxidant genes expression level of GR, GSHPx, Catalase and GST in liver tissue by real time PCR. The dose of $6 \mathrm{mg} / \mathrm{kg}$ showed nearly the same gene expression level of the control group. There was insignificant decreased in all studied antioxidant gene observed by around 0.5 folds at cumulative dose of Dox 12 and $18 \mathrm{mg} / \mathrm{kg}$, as compared to the control group. Interestingly, L-carnitine in combination with high dose of Dox was significantly increased the expression of antioxidant gene GSHPx, CAT and GST by 7.4 , 7.1 and 9.9 folds respectively.

\section{Discussion}

Doxorubicin is potent anticancer drug, whose clinical use is limited on account of its toxicity. ${ }^{30,31}$ It causes disruption in basal metabolism by showing toxic effect especially in liver and heart tissues in animals. ${ }^{1,2}$ It is known that doxorubicin is considered the most toxic anthracyclines $^{15}$ and causes weight loss, ${ }^{32,33}$

for this reason, the long term and over dosage of this drug causes death. Since oxidation stress is considered to be the major event responsible for anthracyclines toxicity. During our experiments we used suitable Dox doses because there was no record for any animal death. The current study investigates whether L-carnitine supplementation could inhibit the hepatotoxicity induced by cumulative dose of doxorubicin in rats.

Data presented in this study demonstrate that doxorubicin increased serum indices of liver function including ALT, ALP and total bilirubin. These elevations of ALT and ALP are attributed to hepatocellular damage and decreased liver functions. These elevated levels of serum indices for hepatocellular damage has been previously reported in Dox-induced hepatoxicity model. ${ }^{34-36}$ Interestingly, L-carnitine prevents the increase in hepatic enzymes during its administration in combination with a cumulative dose of doxorubicin. These results suggested that L-carnitine may have protective effect against Dox-induced liver damage. This protective effect might be due to stabilization of hepatocyte membranes by in Rat liver tissues
Table 3. The effect of doxorubicin on oxidative and nitrosative stress biomarkers in rats

\begin{tabular}{ccccc}
$\begin{array}{c}\text { Treatment } \\
\text { groups } \\
\text { Control }\end{array}$ & TBARS & NO $(\mathbf{x})$ & GSH & SOD \\
$\begin{array}{c}\text { L-Carnitine } \\
\text { Doxorubicin } \\
6 \mathrm{mg} / \mathrm{kg}\end{array}$ & $294.5 \pm 25.02$ & $39.7 \pm 2.49$ & $4.16 \pm 0.22$ & $2.4 \pm 0.238$ \\
$\begin{array}{c}\text { Doxorubicin } \\
12 \mathrm{mg} / \mathrm{kg}\end{array}$ & $332 \pm 18.5 \pm 5.96^{*}$ & $39.1 \pm 2.47$ & $4.0 \pm 0.43$ & $2.5 \pm 0.121$ \\
$\begin{array}{c}\text { Doxorubicin } \\
18 \mathrm{mg} / \mathrm{kg}\end{array}$ & $507.3 \pm 17.38^{*} \#$ & $52.4 \pm 1.77^{*}$ & $2.47 \pm 0.165^{*}$ & $1.9 \pm 0.03^{*}$ \\
$\begin{array}{c}\text { Doxorubicin } \\
18 \mathrm{mg} / \mathrm{kg}+\mathrm{L} \\
\text { Carnitine }\end{array}$ & $223 \pm 35.2^{*} \# \$$ & $49.5 \pm 2.014^{*} \$$ & $2.302 \pm 0.147^{*}$ & $1.18 \pm 0.09^{*}$ \\
\hline
\end{tabular}

Table 4. The effect of doxorubicin on the activity of antioxidant enzymes, glutathione peroxidase (GSHPx), Catalase (CAT), glutathione reductase (GR) and glutathione-s-transferase (GST),

\begin{tabular}{|c|c|c|c|c|}
\hline $\begin{array}{l}\text { Treatment } \\
\text { groups }\end{array}$ & $\begin{array}{c}\text { GSHPx } \mu \mathrm{mol} / \mathrm{g} \\
\text { wet tissue }\end{array}$ & $\underset{\text { tissue }}{\text { CAT } \mu \mathrm{mol} / \mathrm{min} / \mathrm{g}}$ & GR ng/ml & $\underset{\text { tissue }}{\text { GST } \mu \mathrm{mol} / \mathrm{min} / \mathrm{g}}$ \\
\hline Control & $117.5 \pm 3.308$ & $67.5 \pm 1.08$ & $0.953 \pm 0.02$ & $34.2 \pm 1.398$ \\
\hline L-Carnitine & $118.3 \pm 2.983$ & $70.80 \pm 0.789^{*}$ & $0.855 \pm 008^{*}$ & $34.5 \pm 1.08$ \\
\hline $\begin{array}{c}\text { Doxorubicin } \\
6 \mathrm{mg} / \mathrm{kg}\end{array}$ & $83.5 \pm 2.068^{*}$ & $35.4 \pm 0.699^{*}$ & $0.534 \pm 0.05^{*}$ & $21.8 \pm 1.033^{*}$ \\
\hline $\begin{array}{l}\text { Doxorubicin } \\
12 \mathrm{mg} / \mathrm{kg}\end{array}$ & $51.5 \pm 1.509 * \#$ & $37.4 \pm 1.265^{*} \#$ & $0.425 \pm 0.006^{*}$ & $22.0 \pm 1.33^{*}$ \\
\hline $\begin{array}{c}\text { Doxorubicin } \\
18 \mathrm{mg} / \mathrm{kg}\end{array}$ & $42.6 \pm 1.578^{*} \#$ & $26.8 \pm 1.030 * \#$ & $0.27 \pm 0.11^{*} \#$ & $18.1 \pm 0.994^{*} \#$ \\
\hline $\begin{array}{c}\text { Doxorubicin } \\
18 \mathrm{mg} / \mathrm{kg}+\mathrm{L} \\
\text { Carnitine }\end{array}$ & $106.1 \pm 3.510^{*} \# \$$ & $66.3 \pm 0.472 \# \$$ & $1.01 \pm 0.046 \# \$$ & $36.2 \pm 1.398^{*} \# \$$ \\
\hline
\end{tabular}

Table 5. Effect of doxorubicin on the gene expression level of the antioxidant enzymes, glutathione peroxidase (GSHPx), Catalase (CAT), glutathione reductase (GR) and glutathione-s-transferase (GST), in Rat liver tissues

\begin{tabular}{ccccc}
$\begin{array}{c}\text { Treatment } \\
\text { groups }\end{array}$ & GSHPx & CAT & GR & GST \\
$\begin{array}{c}\text { L-Carnitine } \\
\text { Doxorubicin } \\
6 \mathrm{mg} / \mathrm{kg}\end{array}$ & $1.9 \pm 0.288^{*}$ & $1.826 \pm 0.348^{*}$ & $2.268 \pm 0.273^{*}$ & $2.972 \pm 0.338^{*}$ \\
$\begin{array}{c}\text { Doxorubicin } \\
12 \mathrm{mg} / \mathrm{kg}\end{array}$ & $0.588 \pm 0.115$ & $0.415 \pm 0.064^{*}$ & $0.5428 \pm 0.118^{*}$ & $0.688 \pm 0.107$ \\
$\begin{array}{c}\text { Doxorubicin } \\
18 \mathrm{mg} / \mathrm{kg}\end{array}$ & $0.376 \pm 0.090 \#$ & $0.213 \pm 0.047^{*} \#$ & $0.373 \pm 0.052^{*}$ & $0.583 \pm 0.066 \#$ \\
$\begin{array}{c}\text { Doxorubicin } \\
18 \mathrm{mg} / \mathrm{kg}+\mathrm{L} \\
\text { Carnitine }\end{array}$ & $42.6 \pm 1.578^{*} \#$ & $26.8 \pm 1.030^{*} \#$ & $0.27 \pm 0.11^{*} \#$ & $18.1 \pm 0.994^{*} \#$ \\
\hline
\end{tabular}

L-carnitine with the consequent decrease in the leakage of liver enzymes.

Our study established that doxorubicin significantly decrease the total carnitine in liver tissues. This could be a secondary effect following inhibition of endogenous carnitine biosynthesis and/or decreased carnitine transport in Dox-induced hepatocytes damage. This hypothesis is consistent with data presented by Laub 
and his colleagues ${ }^{37}$ which showed that biosynthesis of carnitine is decreased in pediatric patients receiving valproic acid. The level of carnitine in hepatocytes is controlled by the specific carnitine transporter (OCTN-2) and endogenous synthesis. ${ }^{38,39}$ Decreased expression of OCTN-2 has been reported in the acute hepatitis. ${ }^{40}$ Also, OCTN-2 located on hepatocyte membranes might be destroyed when exposed to ROS induced by doxorubicin.

Damage, at the cellular level by oxidants, is attenuated by antioxidant enzyme such as SOD, GSHPx, GSP, CAT and GR. ${ }^{41}$ Superoxide dismutase is one of the major enzymatic antioxidant mechanisms against superoxide radical, prevents liver toxicity induced by Dox. ${ }^{2}$ Catalase and GSHPx catalyze dismutation of the superoxide anion $\left(\mathrm{O}_{2}^{-}\right)$into hydrogen peroxide $\left(\mathrm{H}_{2} \mathrm{O}_{2}\right)$ which then converting $\mathrm{H}_{2} \mathrm{O}_{2}$ to water thus providing protection against reactive oxygen species. ${ }^{42}$ The reduction in activity of these enzymes may be caused by the increase in free radical production during doxorubicin metabolism..$^{32,43}$ Our study showed that cumulative dose of doxorubicin significantly increase both the gene expression level of NOx and TBARS in liver tissue and their enzymatic level in serum. Our study also showed decrease in the gene expression levels of GSHPx, CAT, GR and GST in liver tissue with the cumulative dose of doxorubicin with decrease in their activity in the serum. These data showed that doxorubicin not only increase the free radical formation but also decrease its ability to detoxify reactive oxygen species. The formation of superoxide radicals together with NO might form peroxynitrite induced by doxorubicin causes tissue damage leading to an increase in the levels of TBARs and NOx. This was in agreement with several other reports. ${ }^{2,44}$ In contrast to our study, Kalender and his colleagues ${ }^{45}$ found that administration of doxorubicin ( 5 $\mathrm{mg} /$ week for 6 weeks) increased the levels of TBARs and SOD, and the activity of both GSHPx and catalase enzymes. This difference may be due to the difference in the study design between our study and their.

Antioxidants agent like L-carnitine have been found to offer protection against Dox-induced liver damage. ${ }^{46}$ It was used to prevent the toxic effect of cisplatin-induced nephrotoxicity by normalized kidney function, where oxidative stress and lipid peroxidation play a major role in this toxicity. In addition, L-carnitine attenuated the increased TBARs and reduced GSH levels ${ }^{47}$ in which there were no toxic effects of it on approved doses. Data from this study revealed that L-carnitine administration in combination with doxorubicin significantly increase antioxidant enzyme and decrease the indexes of the lipid peroxidation. The increase in GSH level lead to increase in the activity of GSHPx in which the former acts as a cofactor for later. ${ }^{48}$ Our results are consistent with previous studies reported that L-carnitine had similar non-enzymatic free-radical scavenging and anti-lipid peroxidation activitys. ${ }^{16,49}$

\section{Materials and Methods}

Animals. Adult male Wistar albino rats, weighing 230-250 $\mathrm{g}$, were obtained from the Animal Care Center, College of Pharmacy, King Saud University, Riyadh, Saudi Arabia. Animals were housed in metabolic cages under controlled environmental conditions $\left(25^{\circ} \mathrm{C}\right.$ and a $12 \mathrm{~h} \mathrm{light/dark}$ cycle). Animals had free access to pulverized standard rat pellet diet essentially carnitine free and tap water unless otherwise indicated. The protocol of this study has been approved by Research Ethics Committee of College of Pharmacy, King Saud University, Riyadh, Saudi Arabia.

\section{Materials}

Doxorubicin was a generous gift from King Khaled University Hospital drug store. L-carnitine was kindly supplied by Dr. Zaven Orfalian, Sigma-Tau Pharmaceuticals, Pomezia, Italy. It has been supplied as white powder in a non-commercial plastic bottle contains $100 \mathrm{~g}$ and it was freshly dissolved in normal saline prior to injection. All other chemicals used were of the highest analytical grade.

Experimental design and doxorubicin treatment protocol. In this study, the doxorubicin treatment regimen $(3 \mathrm{mg} / \mathrm{kg}$ every other day) used to develop the cumulative hepatotoxicity was adopted from our previous study with slight modification in which animals were sacrificed 24 hours after cumulative doses of 6,12 and $18 \mathrm{mg} / \mathrm{kg}$. To achieve the ultimate goal of this study, a total of 60 adult male Wistar albino rats were used and divided at random into 6 groups of 10 animals each. Group one was injected intraperitoneally (i.p.) with normal saline $(2.5 \mathrm{ml} / \mathrm{kg})$ and served as a normal control. Group two was injected, every other day, with doxorubicin $(3 \mathrm{mg} / \mathrm{kg}$, i.p.) over a period of 3 days to obtain cumulative dose of $6 \mathrm{mg} / \mathrm{kg}$. Group three was injected, every other day, with doxorubicin ( $3 \mathrm{mg} / \mathrm{kg}$, i.p.) over a period of 7 days to obtain cumulative dose of $12 \mathrm{mg} / \mathrm{kg}$. Animals in the fourth group were injected, every other day, with doxorubicin $(3 \mathrm{mg} / \mathrm{kg}$, i.p.) over a period of 11 days to obtain cumulative dose of $18 \mathrm{mg} /$ $\mathrm{kg}$. Group five was injected with L-carnitine $(200 \mathrm{mg} / \mathrm{kg}$, i.p.) for 10 consecutive days. Animals in the sixth group were received doxorubicin $(18 \mathrm{mg} / \mathrm{kg})$ as group 4 and L-carnitine $(200 \mathrm{mg} / \mathrm{kg})$ as group 5. At 24 hours after receiving the last dose of doxorubicin, animals were anesthetized with ether and blood samples were obtained from the retro-orbital sinus of the eye. Sera were separated for measurement of alanine transaminase (ALT), alkaline phosphatase (ALP), total bilirubin and total nitrate/nitrite (NOx). Immediately after blood samples were collected, animals were then sacrificed by decapitation after exposure to ether in a desiccators kept in a well-functioning hood and their livers were rapidly excised, weighed, washed with saline, blotted with a piece of filter paper and homogenized in normal saline to yield a $10 \%$ $(\mathrm{w} / \mathrm{v})$ tissue homogenate, using a Branson sonifier (250 VWR Scientific, Danbury, CT). Liver specimens from each group were removed and kept in $-80^{\circ} \mathrm{C}$ until used.

\section{Methods}

Detection of gene expression level by real time PCR in liver tissues.

Total RNA extraction. Total RNA were extracted from liver tissue by Trizol method according to the manufacturer's protocol as previously described in reference 50 . The quantity and 
integrity were characterized using a UV spectrophotometer. RNA was electrophorized on ethidium bromide stained agarose gel. The isolated RNA has an A 260/280 ratio of 1.9-2.1.

cDNA synthesis and real time PCR methods. First-strand cDNA was synthesized from $1 \mu \mathrm{g}$ of total RNA by reverse transcription with a SuperScript ${ }^{\mathrm{TM}}$ first-strand synthesis system kit (Invitrogen, CA USA), according to the manufacturer's instructions. Real time PCR was done according to our previous study in reference 1. We used GAPDH gene as housekeeping gene. All primers were listed in Table 1. Following amplification, melting curve analysis was performed to verify the correct product according to its specific melting temperature ( $\mathrm{Tm}$ ).

Determination of free and total carnitine in serum and liver tissues. Liver homogenate was prepared in ice-cold 6\% perchloric acid and centrifuged at 8,000 $\mathrm{g}$ for $10 \mathrm{~min}$. Part of the supernatant was used for the estimation of free carnitine, while the remainder was used for the determination of long-chain acyl carnitine after hydrolysis in $\mathrm{KOH} 1 \mathrm{~mol} / \mathrm{L}$ at $65^{\circ} \mathrm{C}$ for $1 \mathrm{~h}$ as previously described in reference 51 . Carnitine was determined using HPLC after pre-column derivatization with L-aminoanthracene as previously described in reference 52. The mobile phase was prepared by mixing $700 \mathrm{ml}$ of 0.1 $\mathrm{mol} / \mathrm{L}$ ammonium acetate, $\mathrm{pH} 3.5$, with $300 \mathrm{ml}$ of acetonitrile. Chromatographic separation was performed at a flow rate of $1.5 \mathrm{ml} / \mathrm{min}$, using a Kromasil column $(\mathrm{C} 18,25 \mathrm{~cm} \times 4.6 \mathrm{~mm})$ from Saulentechnik Knayer, Berlin, Germany. The excitation and emission wavelengths of the spectrofluorimeter were 248 and $418 \mathrm{~nm}$, respectively.

Determination of glutathione peroxidase, catalase, glutathione transferase, glutathione reductase activity, total nitrate/nitrite and superoxide dismutase. Determination of the activity of glutathione peroxidase (GSHPx) was done as previously described in reference 53 . The changes in the absorbance at $340 \mathrm{~nm}$ were recorded at $1 \mathrm{~min}$ interval for $5 \mathrm{~min}$ and the results were expressed as $\mu \mathrm{mol} / \mathrm{min} / \mathrm{g}$ tissue. The catalase (CAT) activity was determined spectrophotometrically by the method of Pljesa-Ercegovac et al. with slight modification, ${ }^{54}$ the activity was expressed as $\mu \mathrm{mol} / \mathrm{min} / \mathrm{g}$ tissue using the molar absorbance of 43.6 for hydrogen peroxide. Glutathione transeferase activity was assayed as previously described in reference 55. Using 1-chloro-2,4-dinitrobenzene and the results were expressed as $\mathrm{nmol} / \mathrm{min} / \mathrm{mg}$ protein. The glutathione reductase was assayed by ELISA kit (Uscn Life Science Inc., Wuhan) based on sandwich enzyme immunoassay. The activity was expressed as $\mathrm{ng} / \mathrm{ml}$. The nitrite and nitrate (NO) levels were determined according to the previous described method ${ }^{48}$ based on the Griess reaction. Samples were initially deproteinized with Somogyi reagent. Total nitrite was measured by spectrophotometry at $545 \mathrm{~nm}$ after the conversion of $\mathrm{NO}_{2}^{-}$to $\mathrm{NO}_{3}^{-}$by copperized cadmium granules. Results were expressed as micromole per gram tissue protein ( $\mathrm{mmol} / \mathrm{g}$ protein). Tissue SOD activity was determined using the nitroblue tetrazolium (NBT) method described by Sun et al. ${ }^{56}$ and modified by Durak et al. ${ }^{57}$ In this method, NBT is reduced to blue formazan by superoxide $\left(\mathrm{O}_{2}{ }^{-}\right)$, which has a strong absorbance at $560 \mathrm{~nm}$. One unit (U) of SOD is defined as the amount of protein that inhibits the rate of NBT reduction by $50 \%$. SOD activity was expressed as units per $\mathrm{mg}$ tissue protein (U/mg protein).

Statistical analysis. Differences between obtained values (mean \pm SEM, $\mathrm{n}=10$ ) were carried out by one way analysis of variance (ANOVA) followed by the Tukey-Kramer multiple comparison test. A p-value of 0.05 or less was taken as a criterion for a statistically significant difference.

\section{Conclusion}

In conclusion, the present study showed that L-carnitine deficiency is a risk factor and should be viewed as a mechanism in Dox-induced liver damage. The cumulative dose of doxorubicin causes hepatic toxicity as a result of reactive oxygen species may be prevented by L-carnitine supplementation. Therefore, L-carnitine supplementation during Dox treatment may be used to prevent, slow or reverse the occurrence of liver damage.

\section{Acknowledgements}

The present work was supported by operating grant from Research Center, College of Pharmacy, King Saud University (CPRC 080143).

\section{References}

1. Sayed-Ahmed MM, Al-Shabanah OA, Hafez MM, Aleisa AM, Al-Rejaie SS. Inhibition of gene expression of heart fatty acid binding protein and organic cation/ carnitine transporter in doxorubicin cardiomyopathic rat model. Eur J Pharmacol 2010; 640:143-9.

2. Yagmurca M, Bas O, Mollaoglu H, Sahin O, Nacar A, Karaman O, et al. Protective effects of erdosteine on doxorubicin-induced hepatotoxicity in rats. Arch Med Res 2007; 38:380-5.

3. Cai C, Lothstein L, Morrison RR, Hofmann PA. Protection from doxorubicin-induced cardiomyopathy using the modified anthracycline N-benzyladriamycin14-valerate (AD 198). J Pharmacol Exp Ther 2010; 335:223-30.

4. Koka S, Das A, Zhu SG, Durrant D, Xi L, Kukreja RC. Long-acting phosphodiesterase- 5 inhibitor tadalafi attenuates doxorubicin-induced cardiomyopathy without interfering with chemotherapeutic effect. J Pharmacol Exp Ther 2010; 334:1023-30.
5. Kim KH, Oudit GY, Backx PH. Erythropoietin protects against doxorubicin-induced cardiomyopathy via a phosphatidylinositol 3-kinase-dependent pathway. J Pharmacol Exp Ther 2008; 324:160-9.

6. Chen Y, Jungsuwadee P, Vore M, Butterfield DA, St. Clair DK. Collateral damage in cancer chemotherapy: oxidative stress in nontargeted tissues. Mol Interv 2007; 7:147-56.

7. Essick EE, Sam F. Oxidative stress and autophagy in cardiac disease, neurological disorders, aging and cancer. Oxid Med Cell Longev 2010; 3:168-77.

8. Karaman A, Fadillioglu E, Turkmen E, Tas E, Yilmaz Z. Protective effects of leflunomide against ischemiareperfusion injury of the rat liver. Pediatr Surg Int 2006; 22:428-34.

9. Feng YQ, Zuo XL, Li RF, Zhang KJ, Chen F, Xiao H. [Protection against doxorubicin-induced oxidative damage in normal blood cells by naringenin] Zhongguo Shi Yan Xue Ye Xue Za Zhi 2008; 16:790-3
10. Kasapovic J, Pejic S, Stojiljkovic V, Todorovic A, Radosevic-Jelic L, Saicic ZS, et al. Antioxidant status and lipid peroxidation in the blood of breast cancer patients of different ages after chemotherapy with 5-fluorouracil, doxorubicin and cyclophosphamide. Clin Biochem 2010; 43:1287-93.

11. Bouayed J, Bohn T. Exogenous antioxidants-Doubleedged swords in cellular redox state: Health beneficial effects at physiologic doses versus deleterious effects at high doses. Oxid Med Cell Longev 2010; 3:228-37.

12. Al-Rejaie SS, Aleisa AM, Al-Yahya AA, Bakheet SA, Alsheikh A, Fatani AG, et al. Progression of diethylnitrosamine-induced hepatic carcinogenesis in carnitinedepleted rats. World J Gastroenterol 2009; 15:1373-80.

13. Mohamad RH, El-Bastawesy AM, Zekry ZK, Al-Mehdar HA, Al-Said MG, Aly SS, et al. The role of Curcuma longa against doxorubicin (adriamycin)induced toxicity in rats. J Med Food 2009; 12:394-402.

14. Lheureux PE, Hantson P. Carnitine in the treatment of valproic acid-induced toxicity. Clin Toxicol (Phila) 2009; 47:101-11. 
15. Sayed-Ahmed MM, Darweesh AQ, Fatani AJ. Carnitine deficiency and oxidative stress provoke cardiotoxicity in an ifosfamide-induced Fanconi syndrome rat model. Oxid Med Cell Longev 2010; 3:266-74.

16. Augustyniak A, Skrzydlewska E. The influence of L-carnitine suplementation on the antioxidative abilities of serum and the central nervous system of ethanolinduced rats. Metab Brain Dis 2010.

17. Bodea F, Bocea A, Decea N. [L-carnitine decreases oxidative stress induced by experimental hypobaric hypoxia]. Pediatr Endocrinol Diabetes Metab 2010; 16:78-81.

18. Liu J. The effects and mechanisms of mitochondrial nutrient alpha-lipoic acid on improving age-associated mitochondrial and cognitive dysfunction: an overview. Neurochem Res 2008; 33:194-203.

19. Ozsoy S, Ozsoy B, Ozyildiz Z, Aytekin I. Protective effect of L-carnitine on experimental lead toxicity in rats: a clinical, histopathological and immunohistochemical study. Biotech Histochem 2010.

20. Chen HH, Sue YM, Chen CH, Hsu YH, Hou CC, Cheng CY, et al. Peroxisome proliferator-activated receptor alpha plays a crucial role in L-carnitine antiapoptosis effect in renal tubular cells. Nephrol Dial Transplant 2009; 24:3042-9.

21. Crill CM, Helms RA. The use of carnitine in pediatric nutrition. Nutr Clin Pract 2007; 22:204-13.

22. Arduini A, Bonomini M, Savica V, Amato A, Zammit V. Carnitine in metabolic disease: potential for pharmacological intervention. Pharmacol Ther 2008; 120:149-56.

23. Borum PR. Carnitine in parenteral nutrition. Gastroenterology 2009; 137:129-34.

24. Karanth J, Jeevaratnam K. Effect of carnitine supplementation on mitochondrial enzymes in liver and skeletal muscle of rat after dietary lipid manipulation and physical activity. Indian J Exp Biol 2010; 48:503-10.

25. Mate A, Miguel-Carrasco JL, Vazquez CM. The therapeutic prospects of using L-carnitine to manage hypertension-related organ damage. Drug Discov Today 2010; 15:484-92.

26. Thangasamy T, Jeyakumar P, Sittadjody S, Joyee AG, Chinnakannu P. L-carnitine mediates protection against DNA damage in lymphocytes of aged rats. Biogerontology 2009; 10:163-72.

27. Jones LL, McDonald DA, Borum PR. Acylcarnitines: role in brain. Prog Lipid Res 2010; 49:61-75.

28. Morgante G, Scolaro V, Tosti C, Di Sabatino A, Piomboni P, De Leo V. [Treatment with carnitine, acetyl carnitine, 1 -arginine and ginseng improves sperm motility and sexual health in men with asthenopermia]. Minerva Urol Nefrol 2010; 62:213-8.

29. van der Meer PF. Platelet additive solutions: a future perspective. Transfus Clin Biol 2007; 14:522-5.

30. Tangpong J, Miriyala S, Noel T, Sinthupibulyakit C, Jungsuwadee P, St. Clair DK. Doxorubicin-induced central nervous system toxicity and protection by xanthone derivative of Garcinia Mangostana. Neuroscience 2010; In press.
31. Xu M, Sheng L, Zhu X, Zeng S, Chi D, Zhang GJ. Protective effect of tetrandrine on doxorubicin-induced cardiotoxicity in rats. Tumori 2010; 96:460-4.

32. Danz ED, Skramsted J, Henry N, Bennett JA, Keller RS. Resveratrol prevents doxorubicin cardiotoxicity through mitochondrial stabilization and the Sirt 1 pathway. Free Radic Biol Med 2009; 46:1589-97.

33. Panjrath GS, Patel V, Valdiviezo CI, Narula N, Narula J, Jain D. Potentiation of Doxorubicin cardiotoxicity by iron loading in a rodent model. J Am Coll Cardiol 2007; 49:2457-64.

34. Andreadou I, Sigala F, Iliodromitis EK, Papaefthimiou M, Sigalas C, Aligiannis N, et al. Acute doxorubicin cardiotoxicity is successfully treated with the phytochemical oleuropein through suppression of oxidative and nitrosative stress. J Mol Cell Cardiol 2007; 42:549-58.

35. Firat O, Kirdok O, Makay O, Caliskan C, Yilmaz F, Ilgezdi $S$, et al. Can hyperbaric oxygenation decrease doxorubicin hepatotoxicity and improve regeneration in the injured liver? J Hepatobiliary Pancreat Surg 2009; 16:346-52.

36. Cosan D, Basaran A, Gunes HV, Degirmenci I, Ara E. The effect of doxorubicin on rats that received toxic and carcinogenic benzo(a)pyrene. Folia Histochem Cytobiol 2008; 46:367-72.

37. Laub MC, Paetzke-Brunner I, Jaeger G. Serum carnitine during valproic acid therapy. Epilepsia 1986; 27:559-62.

38. Fujita M, Nakanishi T, Shibue Y, Kobayashi D, Moseley RH, Shirasaka Y, et al. Hepatic uptake of gamma-butyrobetaine, a precursor of carnitine biosynthesis, in rats. Am J Physiol Gastrointest Liver Physiol 2009; 297:681-6.

39. Hwu WL, Chien YH, Tang NL, Law LK, Lin CY, Lee NC. Deficiency of the carnitine transporter (OCTN2) with partial N-acetylglutamate synthase (NAGS) deficiency. J Inherit Metab Dis 2007; 30:816.

40. Chang B, Nishikawa M, Nishiguchi S, Inoue M. $\mathrm{L}$-carnitine inhibits hepatocarcinogenesis via protection of mitochondria. Int J Cancer 2005; 113:719-29.

41. Koc A, Duru M, Ciralik H, Akcan R, Sogut S. Protective agent, erdosteine, against cisplatin-induced hepatic oxidant injury in rats. Mol Cell Biochem 2005; 278:79-84.

42. Sayed-Ahmed MM, Aleisa AM, Al-Rejaie SS, Al-Yahya AA, Al-Shabanah OA, Hafez MM, et al. Thymoquinone attenuates diethylnitrosamine induction of hepatic carcinogenesis through antioxidant signaling. Oxid Med Cell Longev 2010; 3:254-61.

43. Fisher-Wellman K, Bell HK, Bloomer RJ. Oxidative stress and antioxidant defense mechanisms linked to exercise during cardiopulmonary and metabolic disorders. Oxid Med Cell Longev 2009; 2:43-51.

44. Injac R, Perse M, Cerne M, Potocnik N, Radic N, Govedarica B, et al. Protective effects of fullerenol $\mathrm{C} 60(\mathrm{OH}) 24$ against doxorubicin-induced cardiotoxicity and hepatotoxicity in rats with colorectal cancer. Biomaterials 2009; 30:1184-96.
45. Kalender Y, Yel M, Kalender S. Doxorubicin hepatotoxicity and hepatic free radical metabolism in rats. The effects of vitamin E and catechin. Toxicology 2005; 209:39-45.

46. Yapar K, Kart A, Karapehlivan M, Atakisi O, Tunca R, Erginsoy S, et al. Hepatoprotective effect of L-carnitine against acute acetaminophen toxicity in mice. Exp Toxicol Pathol 2007; 59:121-8.

47. El-Awady ES, Moustafa YM, Abo-Elmatty DM, Radwan A. Cisplatin-induced cardiotoxicity: Mechanisms and cardioprotective strategies. Eur J Pharmacol 2010.

48. Sayed-Ahmed MM, Aleisa AM, Al-Rejaie SS, Al-Yahya AA, Al-Shabanah OA, Hafez MM, Nagi MN. Thymoquinone attenuates diethylnitrosamine induction of hepatic carcinogenesis through antioxidant signaling. Oxid Med Cell Longev 2010; 3:254-61.

49. Kolodziejczyk J, Saluk-Juszczak J, Wachowicz B. L-carnitine protects plasma components against oxidative alterations. Nutrition 2010.

50. Zekri AR, Hafez MM, Bahnassy AA, Hassan ZK, Mansour T, Kamal MM, et al. Genetic profile of Egyptian hepatocellular-carcinoma associated with hepatitis $\mathrm{C}$ virus Genotype 4 by $15 \mathrm{~K}$ cDNA microarray: preliminary study. BMC Res Notes 2008; 1:106.

51. Alhomida AS. Study of the effects of theophyllinerelated changes in total, free, short-chain acyl and long-chain acyl carnitine concentrations in rat heart. Toxicology 1997; 121:205-13.

52. Cao Y, Wang YX, Liu CJ, Wang LX, Han ZW, Wang CB. Comparison of pharmacokinetics of L-carnitine, acetyl-L-carnitine and propionyl-L-carnitine afte single oral administration of L-carnitine in healthy volunteers. Clin Invest Med 2009; 32:13-9.

53. Lawrence RA, Burk RF. Glutathione peroxidase activity in selenium-deficient rat liver. Biochem Biophys Res Commun 1976; 71:952-8.

54. Pljesa-Ercegovac M, Mimic-Oka J, Dragicevic D, Savic-Radojevic A, Opacic M, Pljesa S, et al. Altered antioxidant capacity in human renal cell carcinoma: role of glutathione associated enzymes. Urol Oncol 2008; 26:175-81.

55. Habig WH, Pabst MJ, Jakoby WB. Glutathione $\mathrm{S}$-transferases. The first enzymatic step in mercapturic acid formation. J Biol Chem 1974; 249:7130-9.

56. Sun Y, Oberley LW, Li Y. A simple method for clinical assay of superoxide dismutase. Clin Chem 1988; 34:497-500.

57. Durak I, Yurtarslanl Z, Canbolat O, Akyol O. A methodological approach to superoxide dismutase (SOD) activity assay based on inhibition of nitroblue tetrazolium (NBT) reduction. Clin Chim Acta 1993; 214:103-4. 


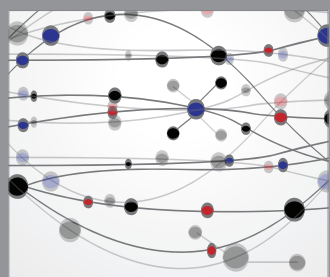

The Scientific World Journal
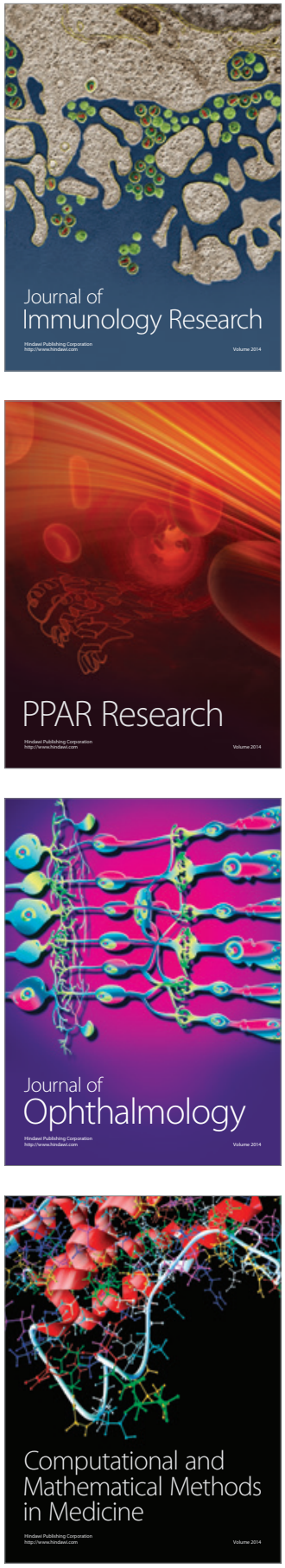

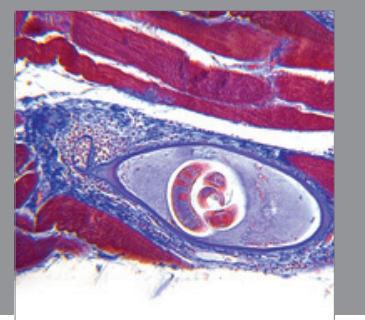

Gastroenterology

Research and Practice
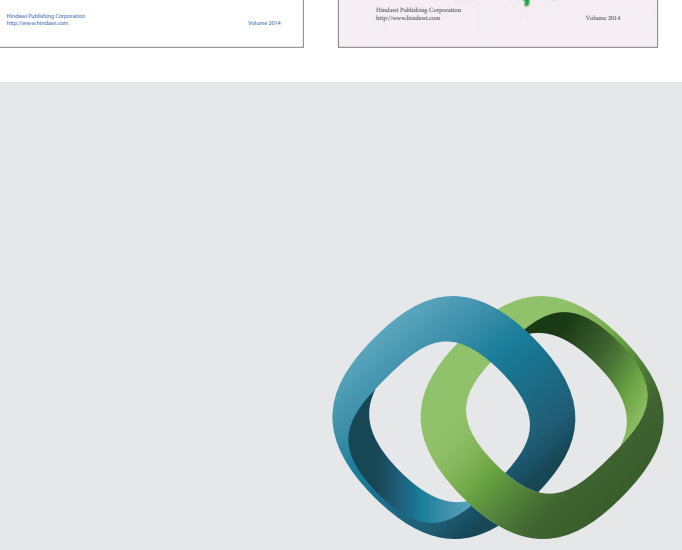

\section{Hindawi}

Submit your manuscripts at

http://www.hindawi.com
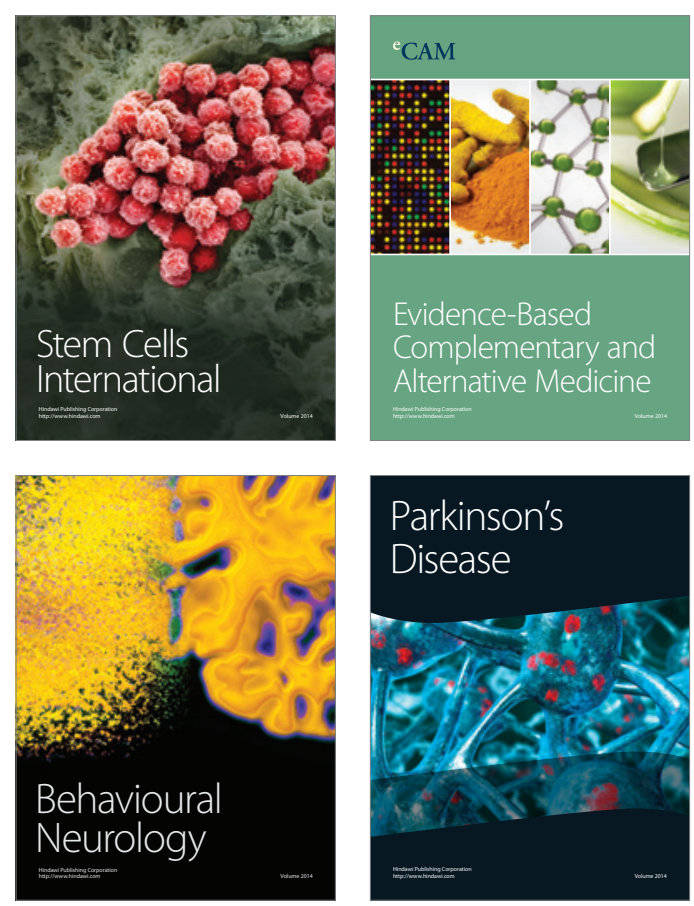

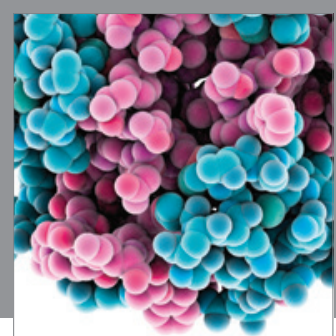

Journal of
Diabetes Research

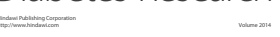

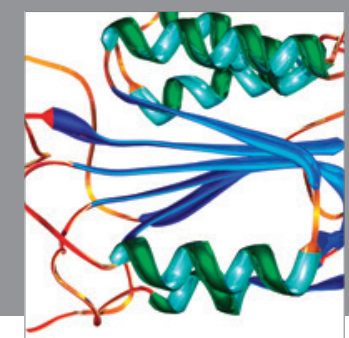

Disease Markers
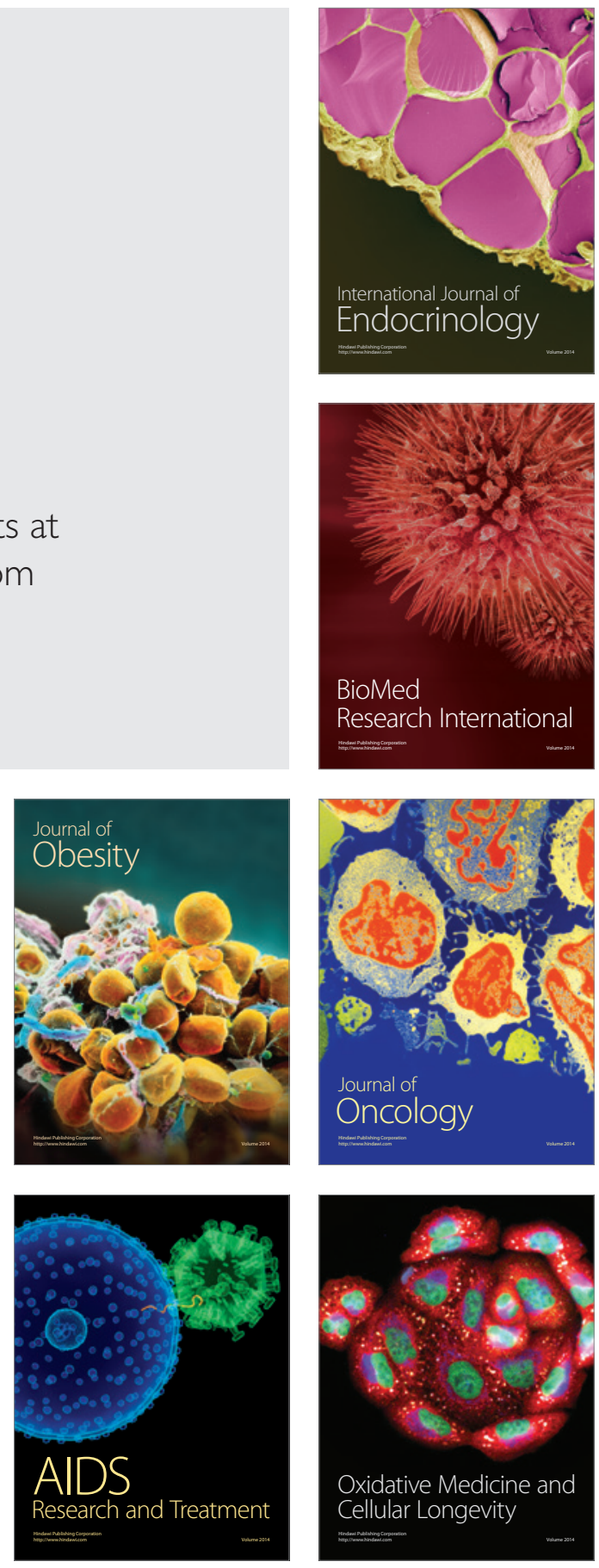